ББК 63.4

\author{
Организация конференциии и издание материалов проведень \\ при финансовой поддержке Российского фонда фундаментальных исследований, \\ проект № 19-09-20008
}

Утверждено к печати Ученым советом ИИМК РАН

Редакционная коллегия тома I: В. А. Алёкшин, Л. Б. Кирчо (отв. редакторы),

В. П. Никоноров, В. Я. Стёганцева; В. В. Терёхина

Рецензенты: д. и. н. Л. Б. Вишняцкий, д. и. н. А. А. Выборнов

Программный комитет конференции: академик РАН, д. и. н., проф. М. Б. Пиотровский

(Государственный Эрмитаж, почетный председатель); д. и. н. В. А. Лапшин (ИИМК РАН, председатель); д. и. н. А. В. Головнёв (МАЭ РАН, сопредседатель); д. и. н. В. А. Дергачёв (Высшая антропологическая школа, Молдова, сопредседатель); д. и. н. И. Ф. Попова (ИВР РАН, сопредседатель); академик АН Республики Узбекистан, д. и. н., проф. Э. В. Ртвеладзе (сопредседатель); к. и. н. А. В. Поляков (ИИМК РАН, зам. председателя); к. и. н. В. А. Алёкшин (ИИМК РАН, зам. председателя); д. и. н. Ю. Е. Берёзкин (МАЭ РАН); Dr., Prof. Н. Бороффка (Германский археологический институт, Германия); В. С. Бочкарёв (ИИМК РАН); Dr. Э. Кайзер (Свободный университет Берлина, Германия); к. и. н. М. Т. Кашуба (ИИМК РАН); д. и. н. Л. Б. Кирчо (ИИМК РАН); к. и. н. А. В. Кияшко (Южный федеральный университет); к. и. н. П. Ф. Кузнецов (СГСПУ);

к. и. н. Н. М. Малов (СНИГУ); к. и. н. В. П. Никоноров (ИИМК РАН); Ю. Ю. Пиотровский

(Государственный Эрмитаж); д. и. н., проф. Д. Г. Савинов (Институт истории СПбГУ);

к. и. н. В. Н. Седых (Институт истории СПбГУ); к. и. н. Н. Н. Скакун (ИИМК РАН);

к. и. н. Н. Ф. Соловьёва (ИИМК РАН); к. и. н. А. И. Торгоев (Государственный Эрмитаж); к. и. н. Е. А. Черлёнок (Институт истории СПбГУ)

Организационный комитет конференции: к. и. н. А. В. Поляков (ИИМК РАН, председатель);

к. и. н. В. А. Алёкшин (ИИМК РАН, зам. председателя); В. С. Бочкарёв (ИИМК РАН); ); к. и. н. М. Т. Кашуба (ИИМК РАН); д. и. н. Л. Б. Кирчо (ИИМК РАН);

А. И. Климушина (ИИМК РАН, отв. секретарь); к. и. н. В. П. Никоноров (ИИМК РАН); Ю. Ю. Пиотровский (Государственный Эрмитаж); В. Я. Стёганцева (ИИМК РАН); В. В. Терёхина

(ИИМК РАН, МАЭ РАН, отв. секретарь); к. и. н. Е. С. Ткач (ИИМК РАН); И. Ж. Тутаева (Государственный Эрмитаж); к. и. н. Е. А. Черлёнок (Институт истории СПбГУ)

Древности Восточной Европы, Центральной Азии и Южной Сибири в контексте связей и взаимодействий в евразийском культурном пространстве (новые данные и концепции): Материалы Международной конференции, 18-22 ноября 2019 г., Санкт-Петербург. Т. I. Древняя Центральная Азия в контексте евразийского культурного пространства (новые данные и концепции). К 90-летию со дня рождения патриарха евразийской археологии Вадима Михайловича Массона. - СПб.: ИИМК РАН, Невская Типография, 2019. — 291 с.

ISBN 978-5-907053-34-2

DOI 10.31600/978-5-907053-34-2 
was a large part of their diet, the consumption of which did not decrease over time, as in other settlements in the region. These and some other facts indicate that residents of Ilgynly Depe, who belonged to the "sanctuary", had certain privileges in comparison with other members of the community.

\title{
CHALCOLITHIC CERAMIC AND ARTEFACTS FROM THE SITE OF MEHRGARH (PERIOD 3), PAKISTAN. CHARACTERISTICS AND COMPARISONS WITH SOME SITES FROM SOUTHERN TURKMENIA
}

\author{
Anaïck Samzun \\ National institute for preventive archaeology, Paris, France \\ DOI: 10.31600/978-5-907053-34-2-32
}

Keywords: Mehrgarh, Pakistan, Chalcolithic, ceramic.

The material culture of the site of period 3 of Mehrgarh (Pakistan) (Chalcolithic period around $4500 \mathrm{BC}$ ) provided with an abundant ceramic specially collected in compartmented mud-brick houses, in a necropol where about 100 tombs have been excavated as well as in an area where remains of a crafmanship area (an oven and hips of sherds) have been excavated. A part the ceramic is decorated and a few motives (caprids, "dansers" etc.) indicate external influences coming from Iran, Afghanistan and Turkmenia. We will discuss about the contacts between Baluchistan and this cultural area.

\section{КЕРАМИКА И АРТЕФАКТЫ ЭПОХИ ЭНЕОЛИТА С ПОСЕЛЕНИЯ МЕРГАР (ПЕРИОД 3), ПАКИСТАН: ХАРАКТЕРИСТИКА И СРАВНЕНИЕ С НЕКОТОРЫМИ ПАМЯТНИКАМИ ЮЖНОГО ТУРКМЕНИСТАНА}

\section{А. Самзун}

Национальньй институт охранной археологии, Париж Франиия

Ключевые слова: Мергар, Пакистан, энеолит, керамика.

Материальная культура поселения Мергарх (Пакистан) периода 3 (эпоха энеолита, около 4500 г. до н. э.) богата керамикой, собранной в домах из сырцового кирпича, на некрополе, где было раскопано около 100 могил, а также на участке, где были открыты остатки ремесленного производства (печь и фрагменты керамики). Часть керамики орнаментирована и некоторые мотивы декора указывают на внешние влияния, исходящие из Ирана, Афганистана и Туркменистана. В докладе обсуждаются контакты между Белуджистаном и этой культурной зоной.

\section{ДАТА ЗАПУСТЕНИЯ ДРЕВНЕЗЕМЛЕДЕЛЬЧЕСКОГО ЦЕНТРА АЛТЫН-ДЕПЕ НА ЮГО-ВОСТОКЕ ТУРКМЕНИСТАНА ${ }^{1}$}

\section{В. А. Алёкшин}

Институт истории материальной культуры РАН, Санкт-Петербург, Россия

DOI: 10.31600/978-5-907053-34-2-32-35

Ключевые слова: Центральная Азия, Северо-Восточный Иран, энеолит, бронзовый век, поселение, клад, Алтын-депе, Гонур-депе, Тепе Гиссар.

Алтын-депе, одно из крупнейших древних поселений юга Центральной Азии, было исследовано Каракумской экспедицией ЛОИА АН СССР/ИИМК РАН с 1965 г. до начала

\footnotetext{
${ }^{1}$ Работа выполнена в рамках программы ФНИ ГАН по теме государственного задания № 01842019-0003 «Генезис древних цивилизаций Центральной Азии (V тыс. до н. э. - I тыс. н. э.) и их взаимодействие с земледельческими центрами Среднего Востока и пастушескими (кочевническими) обществами степной зоны Евразии».
} 